Original Paper

\title{
Pengolahan Rumput Laut Sebagai Camilan Sehat Di Desa Seriwe Kecamatan Jerowaru Kabupaten Lombok Timur
}

\author{
Nunik Cokrowati ${ }^{1 *}$, Rovina Andriani ${ }^{2}$, M. Marzuki ${ }^{1}$ \\ ${ }^{1}$ Program Studi Budidaya Perairan, Fakultas Pertanian, Universitas Mataram, Mataram, Lombok, Indonesia. \\ ${ }^{2}$ Program Studi Budidaya Perairan, Fakultas Perikanan dan Kelautan, Universitas Khairun, Ternate, \\ Indonesia.
}

DOI: $10.29303 /$ jpmpi.v3i2.501

Sitasi: Cokrowati, N., Andriani, R., \& Marzuki, M. (2020). Pengolahan Rumput Laut Sebagai Camilan Sehat Di Desa Seriwe Kecamatan Jerowaru Kabupaten Lombok Timur. Jurnal Pengabdian Magister Pendidikan IPA, 3(2). doi:https://doi.org/10.29303/jpmpi.v3i2.501

*Corresponding Author: Nunik Cokrowati, Program Studi Budidaya Perairan, Fakultas Pertanian, Universitas Mataram, Mataram, Lombok; Email:

nunikcokrowati@unram.ac.id

\begin{abstract}
Abstrak: Desa Seriwe merupakan penghasil rumput laut Eucheuma cottonii kering dan produksinya kontinyu menyumbang produksi rumput laut Pulau Lombok. Rumput laut dapat digunakan sebagai bahan baku makanan dan bahan tambahan makanan olahan. Tujuan kegiatan ini adalah memberikan keterampilan pembuatan camilan sehat berupa dodol dan kerupuk rumput kepada ibu-ibu rumah tangga dan remaja putri. Kegiatan pengabdian kepada masyarakat ini dilakukan dengan menggunakan metode turorial dan praktek langsung pembuatan camilan sehat berupa dodol dan kerupuk rumput laut. Kegiatan dilaksanakan di Desa Seriwe Kecamatan Jerowaru Kabupaten Lombok Timur pada tanggal 8 Desember 2016. Lokasi pelaksanaan kegiatan di ruangan bangunan mini pabrik pengolahan air laut dan rumput laut koperasi Kotoni Desa Seriwe. Kegiatan ini diikuti oleh 15 orang peserta yang terdiri dari ibu-ibu dan remaja putri. Hasil kegiatan ini adalah dodol dan kerupuk rumput laut yang dapat dijadikan camilan sehat keluarga dan dapat juga dijadikan produksaha mikro skala rumah tangga. Kesimpulan dari kegiatan ini adalah keterampilan pembuatan camilan sehat yaitu dodol dan kerupuk rumput telah diberikan tim kegiatan ini kepada kepada ibu-ibu rumah tangga dan remaja putri. Sehingga mereka dapat membuat dan menyediakan secara mandiri camilan sehat tersebut untuk hidangan keluarga.
\end{abstract}

Kata Kunci: Dodol, Kerupuk, Eucheuma cottonii, Ibu rumah tangga, Remaja Putri, Usaha Mikro.

\section{Pendahuluan}

Desa Seriweh terletak di Kecamatan Jerowaru Kabupaten Lombok Timur, berjarak $76 \mathrm{Km}$ dari ibukota Provinsi Nusa Tenggara Barat. Desa Seriwe terdiri dari beberapa dusun yaitu Kaliantan, Seriwe, Temado, Semerang dan Persetapuk (Wafi et al., 2018). Rosyidah et al.,
(2019) menjelaskan Data Dinas Perikanan dan Kelautan Kabupaten Lombok Timur 2016 bahwa potensi lahan budidaya rumput laut di kabupaten Lombok Timur seluas 2.000 hektar, namun yang baru dimanfaatkan hanya seluas 529,78 hektar. Dinas Kelautan dan Perikanan Provinsi NTB memiliki data potensi area budidaya rumput laut di Desa Seriwe adalah 
150 hektar dan telah dimanfaatkan seluas 53 hektar. Produksi rumput laut basah yang dihasilkan pada tahun 2019 sebanyak 195.919,25 ton. Desa Seriwe merupakan penghasil rumput laut Eucheuma cottonii kering dan produksinya kontinyu menyumbang produksi rumput laut Pulau Lombok. Rumput laut dibudidayakan oleh masyarakat setempat dengan menggunakan metode patok dasar, rakit dan longline. Jenis rumput laut yang dibudidayakan adalah Eucheuma cottonii dari bibit konvensional dan bibit hasil kultur jaringan. Cokrowati et al., (2020) pada hasil penlitiannya menjelaskan bahwa bibit rumput laut dari hasil kultur jaringan yang dibudidayakan di Seriweh, menghasilkan pertumbuhan yang lebih optimal dibanding dengan bibit konvensional. Cokrowati, et.al., (2018) menjelaskan bahwa budidaya rumput laut di Teluk Seriwe telah mengoptimalkan ruang perairan dengan cara menggunakan metode budidaya longline pada beberapa kedalaman. Hasil rumput laut yang dibudidayakan hanya dijual dalam bentuk raw material berupa rumput laut kering. Masyarakat tidak memproduksi hasil olahan rumput laut meskipun harga olahan rumput laut lebih tinngi dibandingkan dengan harga rumput laut kering.

Rumput laut dapat digunakan sebagai bahan baku dan bahan tambahan berbagai makanan olahan. Rumput laut mengandung nutrisi yang cukup dan berpotensi dikembangkan sebagai produk pangan (Erniati et al., 2016). Rumput laut memiliki senyawa kimia protektif yang berfungsi sebagai antioksidan, di antaranya senyawa fenol, dietary fiber, PUFA dan fotosintetik pigmen. Senyawa tersebut bermanfaat untuk kesehatan manusia dan dapat dijadikan sebgai pangan fungsional (Sanger, 2018). Rumput laut mengandung nutrisi yang cukup baik dan dapat bermanfaat untuk kesehatan manusia. Makanan olahan berbahan dasar rumput dapat dijadikan camilan sehat sehari-hari di keluarga sehingga dapat mendukung gizi keluarga. Ibuibu rumah tangga dan remaja putri di Desa Seriwe perlu memiliki keterampilan membuat berbagai camilan dari rumput laut. Sehingga rumput laut yang dihasilkan dari budidaya di Seriwe dapat dimanfaatkan sebagai bahan makanan olahan yang dikonsumsi setiap rumah tangga. Pembuatan camilan dari rumput laut juga dapat dijadikan wirausaha dan sebagai lapangan kerja baru bagi masyarakat Seriwe. Tujuan kegiatan ini adalah memberikan keterampilan pembuatan camilan sehat berupa dodol dan kerupuk rumput kepada ibu-ibu rumah tangga dan remaja putri.

\section{Metode Pelaksanaan}

Kegiatan pengabdian kepada masyarakat ini dilakukan dengan menggunakan metode turorial dan praktek langsung pembuatan camilan sehat berupa dodol dan kerupuk rumput laut. Kegiatan dilaksanakan di Desa Seriwe Kecamatan Jerowaru Kabupaten Lombok Timur pada tanggal 8 Desember 2016. Lokasi pelaksanaan kegiatan di ruangan bangunan mini pabrik pengolahan air laut dan rumput laut koperasi Kotoni Desa Seriwe. Koperasi Kotoni merupakan koperasi yang beranggotakan pembudidaya rumput laut di Desa Seriwe. Koperasi ini dibentuk oleh pembudidaya untuk memudahkan pengembangan budidaya rumput laut dan kegiatan lain terkait rumput laut. Peserta dan sasaran kegiatan adalah ibu rumah tangga dan remaja puteri, jumlah total adalah 15 orang.

Kegiatan dilakukan dengan cara paraktek langsung bersama peserta kegiatan membuat dodol dan kerupuk rumput laut. Berikut adalah bahan, peralatan dan cara kerja pembuatan Kerupuk rumput laut.

Tabel 1. Bahan dan alat yang digunakan untuk pembuatan kerupuk rumput laut

\begin{tabular}{ll}
\hline Alat & \multicolumn{1}{c}{ Bahan } \\
\hline 1. Blender & 1. Tepung tapioka 2 kg \\
2. Pisau & 2. Telur ayam 8 butir \\
3. Panci pengukusan & 3. Rumput laut 1 kg \\
4. Kompor dan gas & 4. Bawang putih 4 siung \\
5. Wajan & 5. Ketumbar 1 ons \\
6. Baskom & 6. Gula 1 sendok \\
7. Serok & 7. Garam dan penyedap \\
8. Plastik kemasan & rasa secukupnya \\
9. Talenan & \\
\hline
\end{tabular}


10. Loyang

11. Para-para untuk menjemur.

Cara Kerja:

1. Rumput laut dicuci, dibersihkan dari semua kotoran yang menempel.

2. Rendam rumput laut \pm 3 jam (hingga mengembang)

3. Haluskan rumput laut dengan menggunakan blender hingga menjadi bubur

4. Haluskan bumbu (bawang putih, ketumbar, garam, dll)

5. Campurkan rumput laut, tepung dan bumbu yang telah dihaluskan, kemudian tambahkan telur.

6. Setelah tercampur semua buat adonan kerupuk hingga semua bahan tercampur rata.

7. Cetak adonan kerupuk sesuai selera (bisa menggunakan loyang atau plastik gula).

8. Kukus adonan hingga matang, kemudian setelah dingin potong-potong adonan sesuai selera.

9. Jemur kerupuk hingga kering.

10. Goreng dan siap dikemas.

Kerupuk rumput laut belum familiar di masyarakat, namun sebenarnya karaginan yang terkandung pada rumput laut dapat berfungsi sebagai pengembang dan perenyah. Sehingga kerupuk rumput laut di buat tanpa bahan pengembang dan perenyah.

Dodol rumput laut lebih familiar dan tersaji pada waktu hari raya Idul fitri di kalangan masyarakat Nusa Tenggara Barat. Berikut adalaha bahan, peralatan dan cara pembuatan dodol rumput laut.

Tabel 2. Bahan dan alat yang digunakan untuk pembuatan dodol rumput laut

\begin{tabular}{cll}
\hline \multicolumn{1}{c}{ Alat } & Bahan \\
\hline 1. & Blender & 1. Gula $1 \mathrm{~kg}$ \\
2. Panci perebusan & 2. Essens 1 btl \\
3. Kompor dan gas & 3. Vanilli \\
4. Wajan teflon & secukupnya \\
5. Baskom & 4. Garam \\
6. Serok & secukupnya \\
7. Kemasan & 5. Rumput laut 2 kg \\
8. Talenan & \\
\hline
\end{tabular}

9. Loyang
10. Spatula
11. Sendok kayu besar
12. Ember
13. Kain kassa

Cara Kerja:

1. Rumput laut dicuci, dibersihkan dari semua kotoran yang menempel.

2. Rendam rumput laut \pm 3 jam (hingga mengembang)

3. Masak rumput laut dengan 2 liter air hingga menjadi bubur kemudian saring menggunakan kain kassa (ambil ekstraknya saja)

4. Panaskan ekstrak rumput laut menggunakan wajan sambil di aduk.

5. Tambahkan gula ke dalam adonan dodol rumput laut sambil terus di aduk.

6. Tambahkan essens/pasta beserta vanilli ke dalam adonan sambil terus di aduk hingga adonan kalis/tidak lengket di wajan.

7. Cetak adonan menggunakan loyang sambil diratakan menggunakan spatula.

8. Masukkan adonan ke dalam kulkas hingga keras kemudian potong-potong/bentuk dodol sesuai selera.

9. Dodol siap di kemas.

\section{Hasil dan Pembahasan}

Kegiatan ini dilaksanakan di ruangan pada bangunan mini pabrik pengolahan air laut dan produk rumput laut yang didirikan atas kerjasama Prodi Budidaya Perairan Universitas Mataram, Universitas Persada Jakarta, dan NANZANKAI Jepang. Kegiatan ini diikuti oleh 15 orang peserta yang terdiri dari ibu-ibu dan remaja putri, dengan harapan mereka dapat berperan pada peningkatan gizi rumah tangga. Kegiatan ini juga dihadiri pengurus koperasi Kotoni desa Seriwe. Berikut adalah gambar peserta kegiatan yang sedang menyimak arahan tim pelaksana kegiatan. 


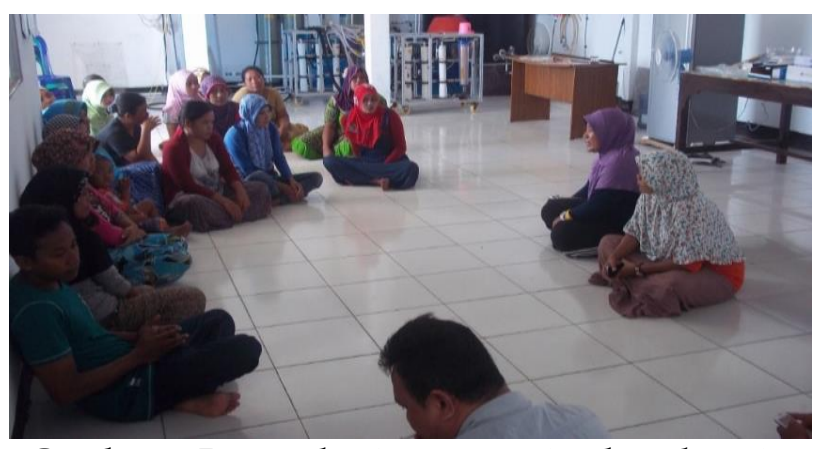

Gambar 1. Peserta kegiatan menyimak arahan tim pelaksana kegiatan

Kegiatan diawali dengan penjelasan tim kegiatan mengenai tujuan dari kegiatan yaitu memberikan keterampilan pembuatan camilan sehat rumput laut dan manfaat gizi rumput laut bagi kesehatan. Pada kegiatan ini juga dijelaskan peluang usaha mikro dengan komoditas hasil olahan rumput laut. Jika usaha mikro tersebut dilakukan maka dapat membantu peningkatan perekonomian keluarga dan meningkatkan perekonomian masyarakat Desa Seriwe. Kegiatan selanjutnya adalah menyiapkan peralatan dan bahan yang digunakan untuk membuat dodol dan kerupuk rumput laut. Keseluruhan peralatan dan bahan disediakan oleh tim kegiatan, dengan harapan perlatan dan bahan tersebut dapat dijadikan modal awal bagi masyarakat untuk memulia usaha mikro pengolahan rumput laut menjadi berbagai produk camilan sehat. Bahan utama yang digunakan adalah rumput laut kering yang telah direndam dengan air tawar selama 24 jam sebagaimana pada gambar dibawah ini.

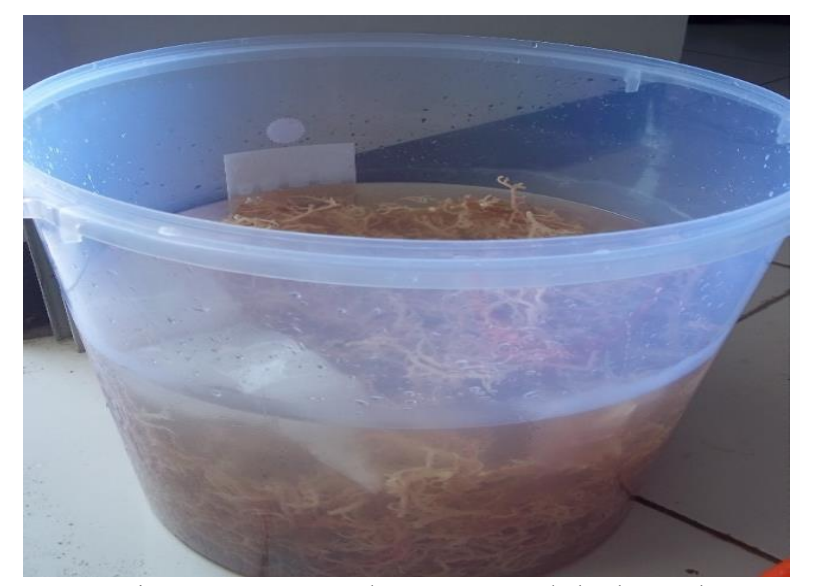

Gambar 2. Rumput laut yang telah direndam menggunakan air tawar.
Rumput laut sebagai bahan baku utama pembuatan dodol dan kerupuk mengandung karaginan yang dapat berfungsi sebagai pengembang, pengenyal, perenyah, dan pengawet alami. Rumput laut mengandung polisakarida yang dapat dimanfaatkan sebagai sumber pangan dan obat-obatan. Merdekawati et al., (2009) menjelaskan rumput laut merupakan tumbuhan laut yang berpotensi sebagai sumber pangan dan obat-obatan. Dewi et al., (2018) menjelaskan hasil penelitiannya bahwa rumput laut Eucheuma cottonii yang diekstraksi menjadi karagenan mengandung asam amino esensial yang bermanfaat bagi tubuh manusia. Asam amino esensial tersebut adalah asam aspartat, asam glutamat, serin, glysine, arginine, alanine, tirosin, metionin, valin, fenilalanin, isoleusin, leusin dan lisin.

Setha et al., (2019) menjelaskan komposisi dasar pembuatan dodol rumput laut adalah rumput laut jenis Eucheuma cottonii dan bahan tambahan seperti gula, garam, tepung, santan kelapa, vanili dan perasa buah jika dikehendaki. Bahan tersebut mudah diperoleh dan terjangkau untuk dibeli masyarakat. Sehingga dapat dengan mudah dodol dibuat oleh ibu-ibu dan remaja putri Desa Seriwe. Ardani (2018).Penambahan rumput laut pada krupuk, dapat menggantikan perenyah berbahaya seperti boraks. Rumput laut memberikan kelebihan yaitu memiliki rasa gurih yang khas, renyah dan juga mempunyai banyak manfaat bagi kesehatan tubuh manusia. Hasil penelitian Septiana et al., (2012) menjelaskan bahwa penambahan rumput laut E. cottonii sebanyak $20 \%$ dapat meningkatkan kerenyahan kerupuk ikan dan tidak menurunkan derajat pengembangan. Namun penambahan rumput laut lebih dari $20 \%$ hingga $40 \%$ dapat menurunkan kerenyahan dan kesukaan serta menurunkan derajat pengembangan kerupuk ikan.

Dodol dan kerupuk rumput laut dapat dijadikan camilan sehat bagi keluarga dan dapat juga dijadikan komoditas usaha rumah tangga. Peserta kegiatan mengikuti kegiatan dengan serius karena mereka juga ingin membuat dodol dan kerupuk rumput laut 
sebagai komoditas usaha kelompok koperasi Kotoni. Berikut gambar peserta saat proses pembuatan dodol.

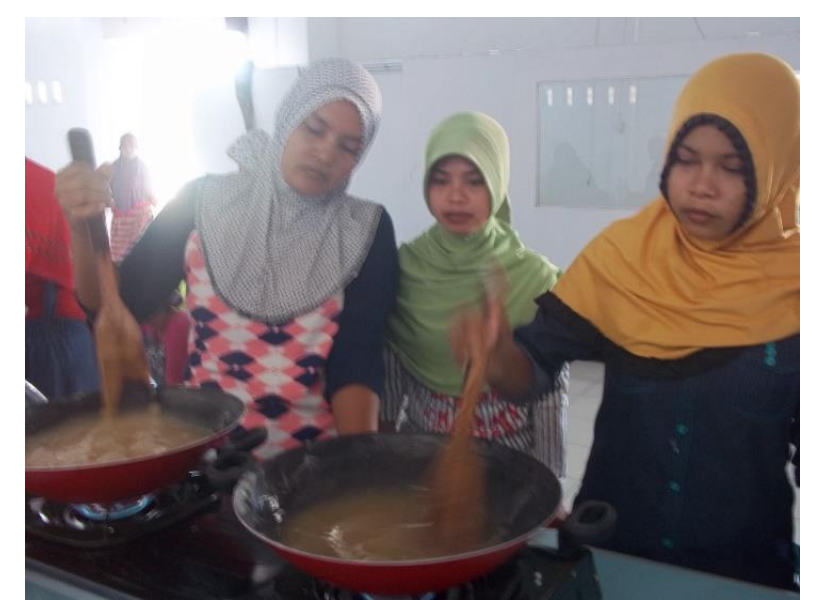

Gambar 3. Peserta mengaduk adonan dodol rumput laut

Pembuatan dodol rumput laut memerlukan waktu relatif lama untuk mengaduk diatas kompor hingga adonan memadat. Kurang lebih dibutuhkan waktu 5 jam untuk mengaduk diatas api kompor. Sehingga untuk selanjutnya diperlukan solusi alat mini yang otomatis untuk mengaduk adonan dodol rumput laut. Sedangkan proses pembuatan kerupuk rumput laut memerlukan waktu yang lebih singkat yaitu 1 jam untuk pembuatan dan pengukusan adonan dan waktu yang diperluakan untuk penjemuran tergantung terik matahari. Jika sinar matahari optimal maka 2 jam penjemuran sudah cukup. Berikut gambar adonan kerupuk rumput laut yang siap direbus.

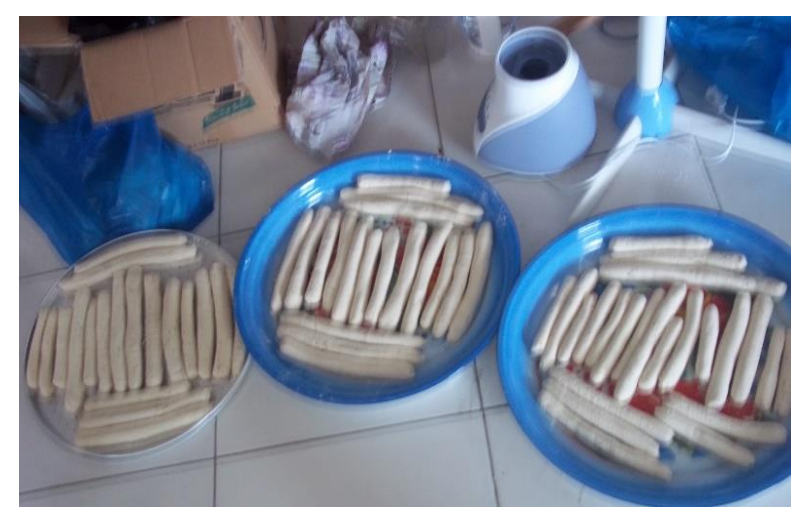

Gambar 4. Adonan kerupuk rumput laut yang siap di kukus.
Pembuatan kerupuk rumput laut ini lebih sehat karena tidak menggunakan bahan pengembang, perenyah dan pengawet sintetis. Rumput laut memiliki fungsi bahan tersebut dan lebih sehat. Hanya saja bau rumput laut tetap khas pada kerupuk, jika tidak suka dengan bau khas tersebut maka dapat ditambahkan perasa lain misalkan rasa balado, keju dan cabe bubuk. Berikut adalah produk yang dihasilkan dari kegiatan ini dan siap dinikmati bahkan siap dijual.

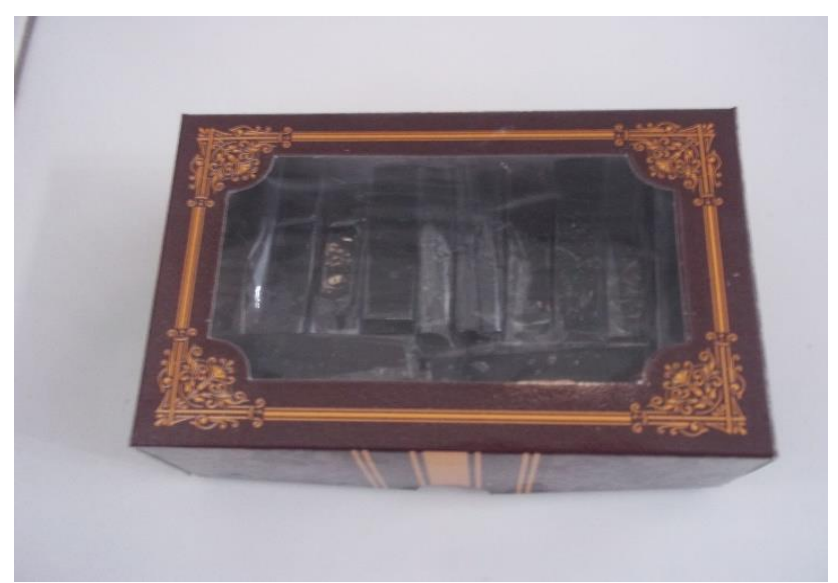

Gambar 4. Dodol rumput laut yang telah dikemas.

Keterampilan pembuatan dodol dan kerupuk rumput laut tersebut dapat membantu meningkatkan gizi dan kesehartan keluarga karena camilan tersebut sehat dan bergizi. Dodol dan kerupuk rumput laut tersebut juga mulai dijadikan produk yang dapat dijual. Produksi dodol dan kerupuk rumput laut diharapkan dilakukan terus menerus dan berlanjut dengan pendampingan dari tim kegiatan ini. Produksi tersebut diharapkan dapat menjadi usaha mikro skala rumah tangga yang dapat membantu meningkatkan perekonomian masyarakat.

\section{Kesimpulan}

Keterampilan pembuatan camilan sehat yaitu dodol dan kerupuk rumput telah diberikan tim kegiatan ini kepada kepada ibuibu rumah tangga dan remaja putri. Sehingga mereka dapat membuat dan menyediakan secara mandiri camilan sehat tersebut untuk 
hidangan keluarga dan produk usaha mikro skala rumah tangga.

\section{Ucapan Terimakasih}

Ucapan terima kasih disampaikan kepada NANZANKAI Jepang dan Universitas Persada Jakarta yang telah mendanai kegiatan ini serta anggota koperasi Kotonii dan masyarakat Desa Seriwe yang telah mendukung kegiatan ini.

\section{Daftar Pustaka}

Ardani, I.S.D., dan Buwono, R. Y. 2018. Studi Mutu Kerupuk Rumput Laut (Eucheuma spinosum) Kaitannya Terhadap Sifat Kimiawi Dan Organoleptik. Samakia: Jurnal Ilmu Perikanan, 9 (1): 18-22 Journal Homepage:

http:// samakia.aperiki.ac.id/index.php/ JSAPI

Cokrowati, N., dan Dewi N.S. 2018. Budidaya Rumput Laut Pada Kedalaman Berbeda. Jurnal Pengabdian Magister Pendidikan IPA.Universitas Mataram. Volume (1) 1 : 86-88. e-ISSN: 2655-5263. DOI: $10.29303 /$ jpmpi.v1i1.225

Cokrowati, N., Nanda, D., Dewi, N. S., dan Alis, M. 2020. Pertumbuhan Rumput Laut Lokal dan Rumput Laut Hasil Kultur Jaringan Kappaphycus alvarezii. Journal of Fisheries and Marine Research. Vol 4 No.1(2020)62-65.

DOI: http://dx.doi.org/10.21776/ub.jfmr .2020 .004 .01 .9

Dewi, E.N., Darmanto, dan Ambariyanto. 2018. Nutrition of Edible Seaweed Kappaphycus alvarezii Related to Difefferent Environmental Coastal Water Condition. Omni-Akuatika. Volume 14 (2) : 59 - 65. ISSN: 1858-3873 print / 2476-9347 online. http://dx.doi.org/10.20884/1.oa.2018.14. 2.544 .

Dinas Kelautan dan Perikanan. 2019. Data Produksi Rumput Laut. Laporan Produksi Rumput laut. Dinas Kelautan dan Perikanan Provinsi Nusa Tenggara Barat.
Erniati, Fransiska, R.Z., Endang, P., dan Dede, Robiatul, A. 2016. Potensi rumput laut: Kajian komponen bioaktif dan pemanfaatannya sebagai pangan fungsional. Acta Aquatica. Volume 3:1 (April, 2016): 12-17. DOI: 10.29103/aa.v3i1.332.

Merdekawati, Windu dan A.B. Susanto. 2009. Kandungan dan Komposisi Pigmen Rumput Laut Serta Potensinya Untuk Kesehatan. Squalen. Vol. 4 No. 2. P: 41-47.

Rosyidah, L., A. Zamroni, dan Tenny, A.,. 2019. Persepsi Pembudidaya Pada Usaha Budidaya Rumput Laut Di Desa Seriwe Kabupaten Lombok Timur. ECSOFiM: Journal of Economic and Social of Fisheries and Marine. Volume 07(01): 69-80. e-ISSN: 2528-5939. Permalink/DOI: http://dx.doi.org/10.21776/ub.ecsofim.2 019.007.01.06.

Septiana, A.T., Herastuti, S.R. dan Sujiman. 2012. Pengaruh Penambahan Rumput Laut Eucheuma cottonii Pada Berbagai Proporsi Daging Ikan Tengiri Terhadap Derajat Pengembangan dan Kerenyahan Kerupuk Ikan Tengiri. Conference Paper. Conference: Seminar Nasional Peran Pertanian Dalam Menunjang Ketahanan Pangan Dan Energi Untuk Memperkuat Ekonomi Nassional Berbasis Sumber Daya Lokal At: Fakultas Pertanian Unsoed.

https://www.researchgate.net/publicati on/288817070_PENGARUH_PENAMBA HAN_RUMPUT_LAUT_Eucheuma_cotto nii_PADA_BERBAGAI_PROPORSI_DAG ING_IKAN_TENGGIRI_TERHADAP_DE RAJAD_PENGEMBANGAN_DAN_KER ENYAHAN_KERUPUK_IKAN_TENGGI RI.

Sanger G, Kaseger BE, Rarung LK, Damongilala L. 2018. Potensi beberapa jenis rumput laut sebagai bahan pangan fungsional, sumber pigmen dan antioksidan alami. Jurnal Pengolahan Hasil Perikanan Indonesia. 21(2): 208-217.

Setha, B., Hairati, A., dan Ferdinand, P. 2019. Analisis Mutu Dodol Rumput Laut 
Eucheuma cottonii Dengan Penambahan Tepung Maizena dan Sari Buah Nenas. AGRITEKNO. Jurnal Teknologi Pertanian. Vol. 8, No. 1: 14-23, Th. 2019. SSN: 23029218 (print) ISSN 2620-9721 (Online). DOI: 10.30598/jagritekno.2019.8.1.14.

Wafi, B.T., dan Armin, S. 2018. Penanggulangan Kirisis Air Bersih Di Desa Seriwe Kecamatan Jerowaru Kabupaten Lombok Timur. Jurnal Geodika Vol.1, No.2, Hal 34- 40. e-ISSN 2549-1830. 